\title{
GEOKIMIA BIJIH DAN KONSENTRAT DARI CEBAKAN TEMBAGA-EMAS PORFIRI GRASBERG, TEMBAGAPURA
}

\section{ORE AND CONCENTRATE GEOCHEMISTRY OF GRASBERG PORPHYRY COPPER-GOLD DEPOSIT, TEMBAGAPURA}

\author{
Ernowo, Bambang Pardiarto, dan Dwi Nugroho Sunuhadi \\ Pusat Sumber Daya Mineral, Batubara dan Panas Bumi \\ ernowo.1972@esdm.go.id
}

\begin{abstract}
ABSTRAK
Cebakan porfiri merupakan salah satu tipe cebakan hidrotermal yang proses pembentukannya berkaitan dengan intrusi porfiritik dengan kontrol struktur geologi yang dominan. Mineralisasi utama terjadi pada zona ubahan potasik berupa mineral-mineral sulfida yang terendapkan secara tersebar atau dalam urat-urat stockwork dan breksi hidrotermal dengan $\mathrm{Cu}$ sebagai kandungan logam paling dominan. Selain $\mathrm{Cu}, \mathrm{Au}$, Mo dan Ag yang sudah umum diekstrak, cebakan tipe porfiri juga mengandung unsur-unsur ikutan yang dapat bernilai ekonomis. Penelitian ini dilakukan untuk mengetahui kandungan unsur-unsur logam dalam bijih dan konsentrat bijih dari cebakan porfiri $\mathrm{Cu}-\mathrm{Au}$ Grasberg dengan tujuan mengetahui jenis unsurunsur ikutan lainnya yang berpeluang untuk dimanfaatkan karena bernilai ekonomis.
\end{abstract}

Metode analisis kimia AAS, ICP-OES, XRF, kolorimetri, spektrofotometri, turbidimetri, volumetri dilakukan terhadap 12 conto bijih terdiri dari masing-masing 3 conto dari jenis bijih MGO, HGO, SGO dan CLO, 11 conto konsentrat serta 1 conto tailing. Spektrofotometri UVVis dilakukan terhadap 2 conto konsentrat untuk mengetahui kandungan $U$ dan Th.

Kadar $\mathrm{Cu}, \mathrm{Au}$ dan Ag terkait dengan kandungan mineral-mineral sulfida di dalam bijih dan sudah terbukti ekonomis. Kadar Te dan Se di dalam bijih masing-masing 2,7 ppm dan 6,4 $\mathrm{ppm}$. Di dalam konsentrat bijih, kadar kedua unsur tersebut meningkat menjadi $16 \mathrm{ppm}$ Te dan 174 ppm Se. Data peneliti lain menunjukkan kandungan platinum group elements (PGE) yaitu $\mathrm{Pd}$ dan Pt di dalam konsentrat bijih masing-masing 1700 ppb dan 650 ppb. Data tersebut menunjukkan unsur-unsur ikutan Te, Se, Pt dan Pd dari cebakan porfiri Cu-Au Grasberg bisa diambil dari lumpur anoda sebagai produk ikutan dari proses pemurnian bijih tembaga.

Kata kunci: Porfiri, Grasberg, konsentrat, PGE, selenium, telurium

\section{ABSTRACT}

Porphyry ore deposit is a hydrothermal deposit type which related to porphyritic intrusion and dominantly controlled by geological structures. The main mineralization occurs in potassic alteration zones as disseminated sulphide minerals or in stockwork veins and hydrothermal breccias with $\mathrm{Cu}$ as the dominant metal. In addition to $\mathrm{Cu}, \mathrm{Au}$, Mo and $\mathrm{Ag}$ which are commonly extracted, porphyry type deposits also contain critical elements which have ecomnomic value known as by-product. This study was conducted to determine the critical elements contain in ore and ore concentrate from Grasberg porphyry $\mathrm{Cu}$-Au deposit in order to find which elements potentially have an economic value.

Chemical analysis methods of AAS, ICP-OES, XRF, colorimetry, spectrophotometry, turbidimetry, volumetry were carried out on 12 ore samples of each 3 samples of ore types MGO, HGO, SGO and CLO, 11 concentrate samples and 1 tailing sample. To determine the grade of $U$ and Th, 2 concentrate samples were analyzed using UV-Vis spectrophotometry. 
The grade of $\mathrm{Cu}, \mathrm{Au}$ and $\mathrm{Ag}$ is related to the content of sulfide minerals inside the ore which economically proven. The grades of $\mathrm{Te}$ and Se from the ore are $2.7 \mathrm{ppm}$ and $6.4 \mathrm{ppm}$, respectively. In the ore concentrate these elements are enriched to $16 \mathrm{ppm}$ Te and $174 \mathrm{ppm}$. Another data shown the platinum group elements (PGE) of $\mathrm{Pd}$ and Pt content in ore concentrates are $1700 \mathrm{ppb}$ and $650 \mathrm{ppb}$, respectively. These values indicate that Te, Se, Pt and Pd from Grasberg Cu-Au porphyry deposit can be recovered from anode slime as byproduct during the refinery process of copper ore.

Keywords: Porphyry, Grasberg, concentrate, PGE, selenium, telurium

\section{PENDAHULUAN}

Cebakan bijih tipe porfiri terbentuk berasosiasi dengan intrusi porfiritik felsik intermediate dengan kontrol struktur geologi yang dominan (Lowell, 1968; Kirkham, 1972; Sillitoe, 1973; Titley and Beane, 1981; Seedorff drr., 2005). Sistem cebakan porfiri pada zona penunjaman berkaitan dengan batuan intrusi monsonit kuarsa, granodiorit, dan diorit yang pada umumnya memiliki afinitas magma kalk-alkalin, meskipun ada sedikit cebakan yang berasosiasi dengan afinitas magma high K-calcalkaline dan alkalin (Cooke drr., 2005).

Mineralisasi dibawa oleh komplek batuan terobosan multifase (Cooke drr, 2014) yang mengendapkan mineral-mineral sulfida pembawa unsur tembaga $(\mathrm{Cu})$, molibdenum (Mo), emas (Au) dan unsur-unsur ikutan lainya secara tersebar akibat proses penggantian mineral penyusun batuan samping maupun dalam urat-urat stockwork dan breksi hidrotermal (Lowell dan Gilbert, 1970; 1990; Seedorff drr., 2005).

Cebakan porfiri paling banyak ditemukan yang mengandung $\mathrm{Cu}$ sebagai komoditas utamanya (porfiri $\mathrm{Cu}-\mathrm{Au}$ ). Bijih $\mathrm{Cu}$ kadar tinggi pada umumnya terkonsentrasi pada urat-urat stockwork yang berada dekat pusat komplek batuan terobosan (Titley, 1990). Beberapa cebakan tipe porfiri memiliki kadar Au sampai $1 \mathrm{ppm}$ yang menjadi kandungan sekunder dari bijih porfiri $\mathrm{Cu}-\mathrm{Au}$ dengan beberapa zona ubahan berdasarkan kehadiran satu atau kombisasi beberapa mineral yaitu potasik, sodik-kalsik, filik, klorit-serisit, argilik, dan propilitik (Ridley, 2013).
Zona potasik sebagai inti terbentuk mengawali evolusi cebakan porfiri dengan komposisi mineral-mineral ubahan berupa kuarsa, K-felspar dan biotit merupakan pembawa mineralisasi utama (Garwin, 2002; Ridley, 2013; Cooke drr., 2014) dengan urat-urat yang mengelilingi pusat batuan intrusi dengan pola radial dan/atau konsentrik di sekeliling pusat intrusi (Cannell drr., 2005; Heidrick dan Titley, 1982).

Cebakan tipe porfiri menghasilkan $\mathrm{Cu}$ dan Mo masing-masing sekitar $65 \%$ dan $95 \%$ dari produksi dunia, serta jumlah signifikan dari Au dengan produk ikutan berupa perak (Ag) dan rhenium (Re) (Sinclair, 2007; Sillitoe, 2010; Ridley, 2013).

Perkembangan teknologi saat ini membawa industri penambangan untuk tidak hanya mengambil bahan-bahan tambang utama seperti tembaga, emas, besi, timbal, seng, nikel, timah dan sejenisnya, namun juga komoditas lain yang disebut sebagai "minor metals" yang merupakan unsur-unsur ikutan dari sebuah cebakan mineral.

Cebakan tipe porfiri juga mengandung unsur-unsur ikutan bernilai ekonomis berupa arsenik (As), bismuth (Bi), galena $(\mathrm{Pb})$, indium $(\mathrm{In})$, seng $(\mathrm{Zn})$, selenium $(\mathrm{Se})$, telurium (Te), paladium ( $\mathrm{Pd}$ ) dan platinum (Pt) (Watterson drr., 1977; Tarkian dan Stribrny 1999; Economou-Eliopoulos dan Eliopoulos 2000; Ayres drr., 2002; Sinclair 2007; Jowett drr., 2013; McLemore, 2018). Dalam kadar kecil juga dijumpai timah (Sn), wolfram $(W)$, thorium $(T)$ uranium $(U)$ dan Logam Tanah Jarang (LTJ) dalam cebakan tipe porfiri (Melfos dan Voudouris, 2012; John dan Taylor, 2016; McLemore, 2018). 
Unsur-unsur logam tersebut mendukung dalam pengembangan teknologi modern dan dapat dikatakan sangat mendesak (critical) diperlukan. Keberadaan logam ikutan tersebut dapat diperhitungkan di dalam produk setengah jadi seperti konsentrat.

Penelitian dilakukan di tambang Grasberg yang merupakan cebakan Cu-Au porfiri di Tembagapura, Kabupaten Mimika, Papua dan dikelola oleh PT Freeport Indonesia. (PT FI) (Gambar 1). Tujuannya untuk mengetahui pengayaan unsur-unsur logam dalam bijih maupun konsentrat tembaga dan kandungan unsur-unsur ikutan dari proses pemurnian tembaga yang kemungkinan memiliki nilai ekonomis.

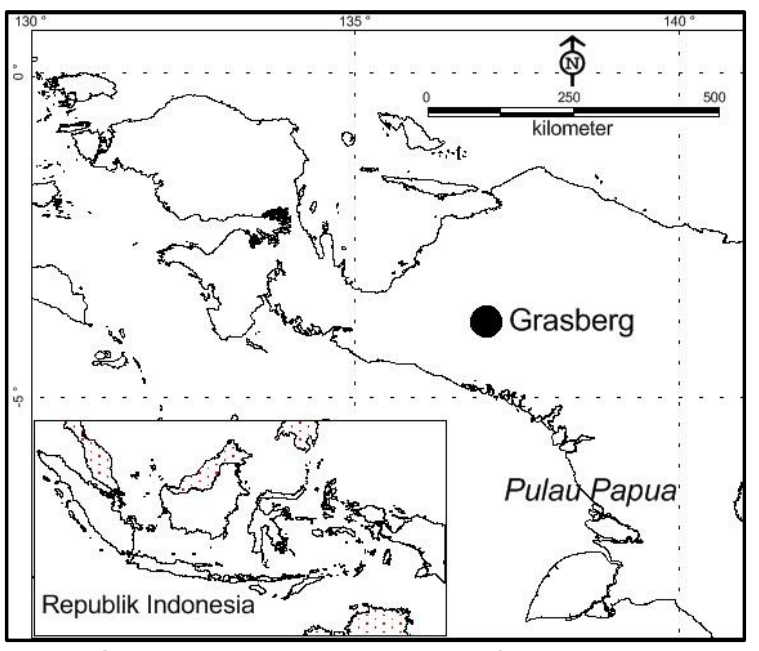

Gambar 1. Peta lokasi Grasberg, Tembagapura

\section{GEOLOGI, MINERALISASI, DAN PENAMBANGAN CEBAKAN TEMBAGA- EMAS PORFIRI GRASBERG}

Cebakan Cu-Au porfiri Grasberg di Tembagapura, Papua, Indonesia diketemukan pada tahun 1988 dan mulai ditambang pada tahun 1989. Grasberg merupakan salah satu cebakan bijih paling kaya di dunia yang mengandung lebih dari 2 milyar ton bijih dengan kandungan $1 \%$ tembaga dan 1 ppm emas, berada di dalam Komplek Intrusi Grasberg yang menerobos batuan silisik klastik dari Formasi Kambelangan berumur Kapur dan Grup Batugamping Papua Nugini berumur Tersier
(Dow drr., 1988; MacDonald dan Arnold, 1994). Komplek Intrusi Grasberg terdiri atas tiga tubuh konsentris yang terbentuk dalam lingkungan subvolkanik yang kemungkinan berhubungan dengan volkanisme maar (Gambar 2). Batuan paling dominan di dalam Kompleks Intrusi Grasberg adalah diatrema Dalam dengan komposisi batuan vulkanik dan intrusif Dalam yang terbreksikan dan mengalami ubahan dalam beberapa tahap yang diterobos oleh uruturutan batuan diorit sampai monzodiorit yaitu diorit Dalam, intrusi utama Grasberg dan intrusi Kali (MacDonald dan Arnold, 1994; Pennington dan Kavalieris, 1997; Pollard dan Taylor, 2002). Diorit Dalam berukuran halus dan merupakan fase akhir dari intrusi Dalam. Intrusi utama Grasberg merupakan batuan monzodiorit porfiri berukuran butir sedang-kasar. Intrusi Kali dibedakan menjadi 3 tipe yaitu: yang paling dominan retas Kali I dengan tekstur porfiritik berukuran halus dengan $40-40 \%$ berupa fenokris yang mengandung plagioklas, amfibol, biotit, klinopiroksen, magnetit dan sedikit kuarsa; retas Kali II yang muncul dalam skala meter, tekstur seriate sampai porfiritik lemah, ukuran butir sedang, 10 sampai $15 \%$ komposisi batuan terdiri dari amfibole, biotit dan magnetit; retas Kali III berupa granit aplitik dalam skala sentimeter - desimeter yang memotong retas Kali I dan Kali II (Pollard dan Taylor, 2002). Kompleks intrusi tersebut menerobos Formasi Kais dari Grup Batugamping Papua Nugini.

Semua tipe ubahan hidrotermal seperti halnya yang umum terdapat pada cebakan tipe porfiri di dunia meliputi potasik, propilitik, pilik dan argilik muncul pada masing-masing fase batuan terobosan di Grasberg.

Mineralisasi Cu-Au-Ag di Grasberg merupakan hasil dari tiga fase utama yang saling terpisah (MacDonald dan Arnold, 1994). Fase mineralisasi pertama terkait dengan diatrema Dalam yang menghasilkan mineralisasi Cu-Au tipe tersebar yang kuat, dengan zona stockwork yang kurang berkembang dengan kadar rata-rata $\mathrm{Cu}$ dan Au masing-masing $1,2 \%$ dan $0,4 \mathrm{ppm}$ ). Fase mineralisasi kedua mengikuti 
terbentuknya intrusi utama Grasberg. Pada intrusi utama Grasberg ini terbentuk zona urat-urat stockwork kuarsa-magnetit-sulfida yang menempati $10 \%$ sampai $70 \%$ volume batuan. Kandungan $\mathrm{Cu}$ dan $\mathrm{Au}$ pada zona ini masing-masing bisa mencapai 2,5\% dan 5,5 ppm. Fase mineralisasi ketiga terkait dengan retas-retas Kali. Pada fase paling lemah ini menghasilkan rata-rata $1 \%$ Cu dan 1 ppm Au. Kisaran umur minimum dari batuan intrusi diindikasikan dari sejumlah penarikan radioaktif $\mathrm{K}$-Ar yang memberikan kisaran 0,6 juta tahun dengan pusat pada 3 juta tahun yang lalu kemungkinan mencerminkan periode mineralisasi paling muda (McDowell drr., 1994; MacDonald and Arnold, 1994).

Heavy Sulfide Zone merupakan zona masif yang kaya akan pirit berukuran halus mengelilingi Kompleks Intrusi Grasberg. Pirit mengganti batuan intrusi yang mengalami ubahan karbonat dan silisifikasi, serisitisasi, feldspatisasi dan magnetit. Penamaan Heavy Sulfide Zone ini oleh Ahli Geologi yang melakukan eksplorasi, dimana pemboran pada zona itu memberikan inti bor yang berat (MacDonald and Arnold, 1994). Berdasarkan kadar Cu, $\mathrm{Au}$ dan $\mathrm{Ag}$ yang diekuivalenkan ke dalam kadar $\mathrm{Cu}$, bijih di Grasberg dikelompokkan dalam empat kelas yaitu Clay Problematic Ore (CLO), merupakan bijih yang mengandung gangue mineral serisit diatas $10 \%$ dan pirit lebih dari 5\%, Medium Grade Ore (MGO), High Grade Ore (HGO), dan Super Grade Ore (SGO) (Tabel 1; Gambar 2).

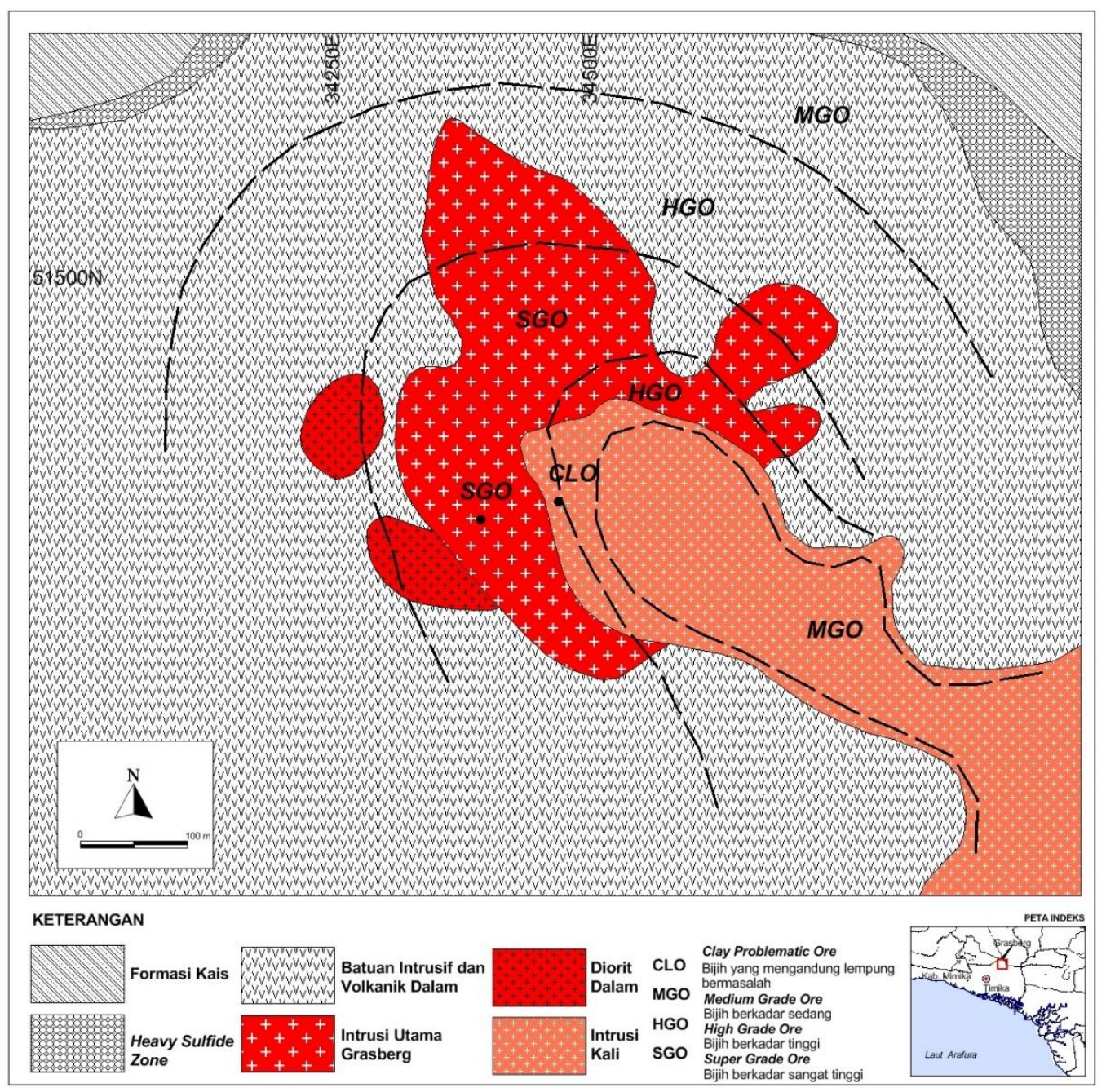

Gambar 2. Peta geologi daerah komplek batuan terobosan Grasberg (modifikasi dari Pollard drr., 2005 dan PT FI Geology GeoEngineering Division, 2018) 
Bijih hasil penambangan terbuka maupun bawah tanah Grasberg diangkut ke pabrik pengolahan untuk dihancurkan menjadi material berukuran pasir sangat halus. Material bijih tersebut kemudian diapungkan (flotation) menggunakan reagent berupa bahan yang berbasis alkohol dan kapur untuk memisahkan konsentrat yang mengandung mineral-mineral berharga dari pasir sangat halus yang dianggap tidak memiliki nilai ekonomi (tailing).

Tabel 1. Pembagian bijih di Grasberg berdasarkan kadar ekuivalen tembaga (EqCu) (PT FI Geology GeoEngineering Division, 2018)

\begin{tabular}{l|l}
\hline Kategori & Kadar \\
\hline CLO & EqCu $\geq 0,25$ \\
MGO & $0,25 \leq$ EqCu $<1$ \\
HGO & $1 \leq$ EqCu $<2,5$ \\
SGO & EqCu $\geq 2,5$ \\
\hline
\end{tabular}

Konsentrat tembaga hasil proses flotasi dari Tembagapura, oleh PT FI ada yang diekspor langsung dan ada yang dikirim ke pabrik pemurnian PT Smelting di Gresik. Pemurnian dilakukan melalui proses pyrometallurgy dan electrolytic refinery sehingga menghasilkan beberapa produk diantaranya copper cathode dan anode slime (lumpur anoda). Dalam lumpur anoda inilah unsur-unsur selain $\mathrm{Cu}$ yang merupakan unsur ikutan terkonsentrasi.

\section{METODOLOGI}

Sebanyak 12 conto bijih terdiri dari masingmasing 3 conto CLO, MGO, HGO dan SGO yang sudah dihancurkan menjadi pasir halus diambil dari grinding ore process di Tembagapura. Demikian juga sebanyak 11 conto konsentrat dan 1 conto tailing diambil dari hasil proses flotasi.

Analisis kimia dilakukan di Laboratorium Pusat Sumber Daya Mineral Batubara dan Panas Bumi terhadap semua conto dengan beberapa metode meliputi :

- AAS untuk analisis unsur $\mathrm{Cu}, \mathrm{Pb}, \mathrm{Zn}$. Co, $\mathrm{Ni}, \mathrm{Mn}, \mathrm{Ag}, \mathrm{Li}, \mathrm{Fe}, \mathrm{Bi}, \mathrm{Ca}, \mathrm{Cd}, \mathrm{Mg}, \mathrm{Cr}, \mathrm{Au}$, Al.
- kolorimetri untuk analisis unsur V, Sb, Sn, As.

- ICP-OES untuk analisis unsur Sc. Zr, La, $\mathrm{Ce}, \mathrm{Pr}, \mathrm{Nd}, \mathrm{Sm}, \mathrm{Eu}, \mathrm{Gd}, \mathrm{Tb}, \mathrm{Dy}, \mathrm{Ho}, \mathrm{Y}$, Er, Tm, Yb, Lu

- XRF untuk analisis unsur Se, Rb, Nb, Mo, Te, Ta, W

- spektrofotometri untuk analisis $\mathrm{SiO}_{2}, \mathrm{Ti}, \mathrm{F}$

- turbidimetri untuk unsur S

- valumetri untuk unsur $\mathrm{Cl}$

Analisis kandungan unsur radioaktif $U$ dan Th di Laboratorium Pusat Teknologi Bahan Galian Nuklir, Badan Tenaga Nuklir Nasional terhadap 2 conto konsentrat bijih dengan metode Spektrofotometri UV-Vis.

\section{HASIL DAN ANALISIS}

Karakteristik megaskopis masing-masing jenis bijih dari Grasberg diwakili oleh contoconto pada Gambar 3. Conto MGO diambil dari Intrusi Kali bagian selatan berupa diorit berwarna abu-abu yang memiliki tekstur porfiritik dan mengalami ubahan potasik menyebar. Komposisi mineral yang menyusun MGO adalah potasium (K)feldspar, plagioklas dan kuarsa, dengan klorit setempat-setempat mengganti biotithornblenda. Kuarsa-anhidrit mengisi urat stockwork. Mineralisasi pada MGO terdiri dari pirit $( \pm 2 \%)$, kalkopirit (1-2\%), bornit dan kovelit $( \pm 0,5 \%)$ (Gambar 3.a).

Conto HGO merupakan bagian dari Intrusi Utama Grasberg yang berupa batuan diorit berwarna abu-abu gelap, dengan tekstur porfiritik dan mengalami ubahan potasik menyebar. Komposisi mineral utamanya adalah K-feldspar, plagioklas, kuarsa, biotit, hornblenda dengan kuarsa-anhidrit-gipsum mengisi urat stockwork. Mineralisasi pada HGO berupa kalkopirit (4\% s.d. $5 \%$ ), bornit dan kovelit $(2 \%$ s.d. $3 \%)$ serta pirit $(<1 \%)$ baik mengisi urat maupun tersebar pada batuan (Gambar 3.b).

Conto SGO juga diambil dari diorit Intrusi Utama Grasberg yang berwarna abu-abu muda dan mengalami ubahan potasik menyebar. Mineral penyusun conto SGO terdiri dari K-feldspar, plagioklas, kuarsa, biotit dan hornblenda dengan mineralisasi 


\section{MAKALAH ILMIAH}

berupa kalkopirit (6\% s.d. $7 \%$ ), bornit-kovelit $(3 \%$ s.d. $5 \%)$ serta pirit $(<0,5 \%)$ yang mengisi urat maupun tersebar pada batuan (Gambar 3c).

Pada semua jenis bijih dijumpai adanya CLO yang mengandung serisit lebih dari $10 \%$. Conto CLO dan diambil dari diorit Intrusi Kali bagian selatan, berwarna abuabu yang mengalami ubahan seritisisasi overprint (menimpas) ubahan potasik. Komposisi mineral terdiri dari serisit, anhidrit dan gipsum baik sebagai masa dasar maupun urat, biotit sekunder dan feldspar. Mineralisasi didominasi oleh pirit $( \pm 7 \%)$, kalkopirit $(2 \%$ s.d. $3 \%)$ dan bornit $( \pm 0,5 \%)$ (Gambar 3.d).

Sebagai unsur bijih utama, kadar $\mathrm{Cu}$ pada CLO berkisar antara 0,8\% sampai 2,94\% serta di dalam MGO, HGO dan SGO masing masing $0,24 \%$ s.d. $0,46 \%, 0,37 \%$ s.d. $0,52 \%$ dan $1,16 \%$ s.d. $2,46 \%$. Sementara itu unsur yang merupakan produk samping dari bijih tembaga yaitu $\mathrm{Au}$ menunjukkan hasil analisis yang variatif dalam CLO yaitu 0,85 ppm sampai kadar yang sangat tinggi 4,77 ppm dan kadar yang relatif seragam pada masing-masing tipe bijih MGO, HGO dan SGO yaitu 0,36 ppm s.d. 0,53 ppm, 0,57 ppm s.d. 0,79 ppm dan 2,21 ppm s.d. 3,31 ppm. Demikian pula kadar Ag dalam CLO, MGO, HGO, dan SGO masing-masing adalah 6 ppm s.d. 9 ppm, 3,2 ppm s.d. 3,8 ppm, 3,5 ppm s.d. 3,8 ppm dan 5,6 ppm s.d. 9,1 ppm.

Molibdenum pada bijih memiliki kadar 5,33 ppm s.d. 47,17 ppm dalam CLO, 5 ppm s.d. 13,73 ppm dalam MGO, 4,06 ppm s.d. 8,57 ppm pada HGO, dan 30,81 ppm s.d. 56,89 ppm pada SGO.

Kandungan unsur radioaktif dan unsur ikutan lain yang terkandung di dalam bijih terangkum dalam hasil analisis kimia yang ditampilkan pada Tabel 2. (a)

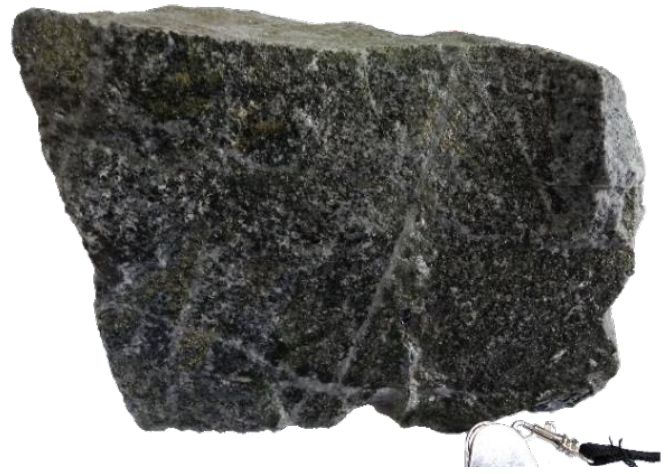

(c)

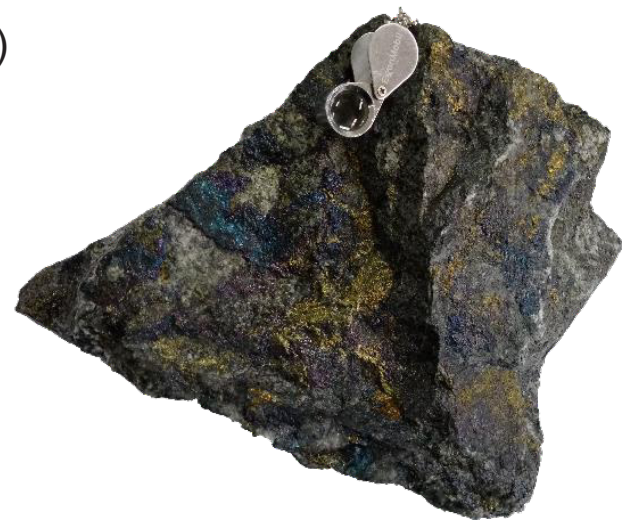

(b)

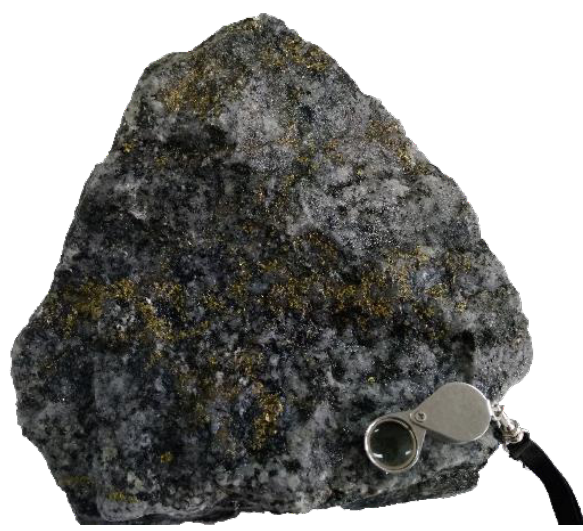

(d)

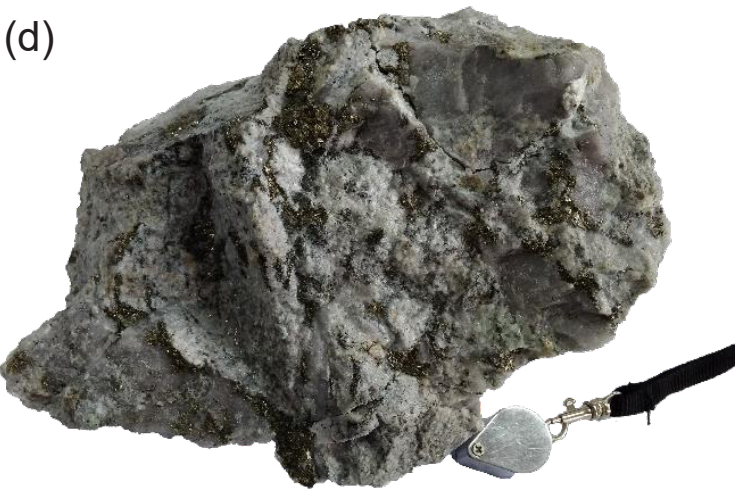

Gambar 3. Conto jenis bijih dari cebakan tembaga-emas porfiri Grasberg berupa (a) MGO, (b) HGO, (c) SGO) dan (d) CLO 
Tabel 2. Hasil analisis kimia conto bijih dari Grasberg

\begin{tabular}{|c|c|c|c|c|c|c|c|c|c|c|c|c|c|}
\hline No. & Conto & MGO_1 & MGO_2 & MGO_3 & HGO_1 & HGO_2 & HGO_3 & SGO_1 & SGO_2 & SGO_3 & CLO_1 & CLO_2 & CLO_3 \\
\hline$\overline{\mathrm{Cu}}$ & $(p p m)$ & 3313 & 4643 & 2437 & 3745 & 5296 & 4995 & 24600 & 14800 & 11600 & 8013 & 9475 & 29400 \\
\hline $\mathrm{Au}$ & $(p p m)$ & 0,536 & 0,409 & 0,364 & 0,785 & 0,578 & 0,797 & 2,918 & 3,111 & 2,214 & 1,433 & 0,855 & 4,776 \\
\hline $\mathrm{Ag}$ & (ppm) & 3,5 & 3,8 & 3,2 & 3,8 & 3,7 & 3,5 & 9,1 & 7,1 & 5,6 & 6,0 & 6,7 & 9,0 \\
\hline $\mathbf{P b}$ & $(p p m)$ & 25 & 39 & 40 & 37 & 26 & 22 & 30 & 22 & 20 & 33 & 75 & 27 \\
\hline $\mathrm{Zn}$ & $($ ppm) & 137 & 152 & 123 & 96 & 66 & 59 & 53 & 50 & 55 & 124 & 265 & 70 \\
\hline Co & $(p p m)$ & 24 & 24 & 25 & 25 & 24 & 20 & 15 & 21 & 24 & 28 & 60 & 65 \\
\hline $\mathrm{Ni}$ & (ppm) & 10 & 11 & 5 & 13 & 13 & 9 & 36 & 11 & 7 & 21 & 18 & 17 \\
\hline Mn & $(p p m)$ & 334 & 600 & 521 & 319 & 248 & 114 & 276 & 244 & 109 & 661 & 178 & 358 \\
\hline Li & $(p p m)$ & 3 & 3 & 3 & 3 & 2 & 3 & 3 & 4 & 3 & 4 & 2 & 2 \\
\hline $\mathbf{F e}$ & (\%) & 2,90 & 2,92 & 3,20 & 4,64 & 5,51 & 4,77 & 1,52 & 4,61 & 4,40 & 4,69 & 7,72 & 14,36 \\
\hline $\mathrm{Bi}$ & $(p p m)$ & 34 & 30 & 28 & 28 & 24 & 24 & 24 & 28 & 26 & 28 & 29 & 28 \\
\hline $\mathrm{Ca}$ & $(p p m)$ & 34200 & 36000 & 30500 & 25400 & 19200 & 26300 & 25900 & 34800 & 28200 & 18100 & 5195 & 5157 \\
\hline Cd & $(p p m)$ & 6 & 6 & 6 & 6 & 6 & 5 & 4 & 6 & 6 & 5 & 6 & 6 \\
\hline Mg & $(p p m)$ & 6099 & 6131 & 5552 & 2614 & 4452 & 5019 & 4222 & 7377 & 7517 & 4657 & 3200 & 3866 \\
\hline $\mathrm{Cr}$ & $(p p m)$ & 229 & 283 & 302 & 205 & 611 & 420 & 484 & 451 & 488 & 545 & 778 & 775 \\
\hline A & (\%) & 7,97 & 7,58 & 7,89 & 7,94 & 6,65 & 6,91 & 7,21 & 7,69 & 10,40 & 5,91 & 5,04 & 3,95 \\
\hline $\mathrm{Ti}$ & (\%) & 0,22 & 0,28 & 0,24 & 0,25 & 0,22 & 0,20 & 0,26 & 0,29 & 0,18 & 0,20 & 0,19 & 0,14 \\
\hline SiO & (\%) & 56,43 & 56,05 & 61,69 & 58,17 & 61,21 & 61,02 & 60,29 & 57,37 & 51,18 & 64,2 & 55,69 & 48,92 \\
\hline v & $($ ppm) & 20 & 30 & 30 & 50 & 150 & 40 & 100 & 80 & 70 & 80 & 40 & 40 \\
\hline Sb & $($ ppm) & 1 & 1 & 1 & 1 & 1 & 1 & 1 & 1 & 1 & 1 & 1 & 1 \\
\hline Sn & (ppm) & bdl & bdl & bdl & bdl & bdl & bdl & bdl & bdl & bdl & bdl & bdl & bdl \\
\hline As & $(p p m)$ & bdl & 4 & bdl & bdl & bdl & bdl & 4 & 40 & bdl & bdl & 4 & bdl \\
\hline Sc & $($ ppm) & 4,23 & 4,13 & 4,83 & 5,50 & 4,06 & 4,30 & 4,76 & 6,50 & 6,89 & 3,85 & 3,04 & 3,01 \\
\hline $\mathrm{Zr}$ & $(p p m)$ & 30,29 & 13,05 & 18,53 & 9,27 & 3,74 & 6,38 & 1,25 & 2,79 & 3,73 & 48,44 & 14,21 & 10,61 \\
\hline $\mathbf{R b}$ & (ppm) & 77,18 & 79,43 & 83,25 & 99,37 & 85,29 & 85,72 & 96,20 & 112,30 & 108,20 & 78,09 & 94,35 & 83,89 \\
\hline Nb & $(p p m)$ & 5,87 & 6,44 & 6,66 & 6,23 & 3,79 & 4,88 & 5,70 & 6,30 & 6,50 & 4,21 & 3,52 & 2,63 \\
\hline Mo & $(p p m)$ & 13,73 & 5,37 & 5,00 & 4,06 & 8,57 & 4,81 & 56,89 & 40,05 & 30,81 & 5,33 & 15,50 & 47,17 \\
\hline Te & (ppm) & bdl & bdl & bdl & bdl & bdl & 2,59 & bdl & 50 & ,30 & bdl & bdl & 5,45 \\
\hline Ta & $(p p m)$ & 2,98 & 7,32 & 4,10 & 2,81 & 5,00 & 89 & 3,00 & 19,90 & 17,30 & 11,69 & 6,95 & 44,05 \\
\hline $\mathbf{w}$ & $($ ppm) & 10,75 & 11,16 & 7,15 & 12,77 & 14,33 & 11,55 & 17,55 & 14,73 & 11,71 & 14,81 & 21,58 & 30,53 \\
\hline $\mathrm{Se}$ & (ppm) & 2,68 & 2,40 & bdl & 1,90 & 4,36 & 4,40 & 9,60 & 8,60 & 7,30 & 4,70 & 8,22 & 16,17 \\
\hline $\mathbf{S}$ & (\%) & 2,59 & 2,59 & 0,79 & 0,16 & 0,16 & 1,18 & 3,78 & 1,73 & 1,72 & 0,16 & 9,22 & 13,90 \\
\hline CI & (\%) & bdl & bdl & bdl & bdl & bdl & bdl & bdl & bdl & bdl & bdl & bdl & bdl \\
\hline La & $($ ppm) & 22,66 & 20,22 & 20,78 & 12,92 & 8,51 & 11,13 & 14,46 & 13,80 & 13,79 & 14,51 & 6,51 & 6,00 \\
\hline $\mathrm{Ce}$ & (ppm) & 45,57 & 44,52 & 38,55 & 28,07 & 22,37 & 25,06 & 33,78 & 27,06 & 30,78 & 29,07 & 15,63 & 15,27 \\
\hline Pr & $(p p m)$ & bdl & bdl & bdl & bdl & bdl & bdl & bdl & bdl & bdl & bdl & bdl & bdl \\
\hline Nd & $($ ppm) & 16,31 & 13,83 & 13,27 & 8,29 & 4,89 & 7,05 & 11,42 & 7,52 & 9,40 & 7,98 & 4,15 & 0,64 \\
\hline Sm & $(p p m)$ & 8,94 & 8,18 & 7,79 & 8,03 & 5,32 & 7,16 & 7,51 & 7,97 & 7,35 & 8,00 & 6,19 & 6,56 \\
\hline Eu & (ppm) & bdl & bdl & bdl & bdl & bdl & bdl & bdl & bdl & bdl & bdl & bdl & bdl \\
\hline Gd & $(p p m)$ & 6,86 & 6,94 & 6,39 & 6,96 & 7,90 & 7,02 & 4,38 & 7,46 & 7,90 & 7,65 & 9,86 & 13,32 \\
\hline Tb & $(p p m)$ & 1,67 & 2,16 & 1,76 & 2,93 & 2,70 & 2,66 & 1,36 & 1,68 & 2,23 & 2,30 & 2,34 & 4,11 \\
\hline Dy & $(p p m)$ & bdl & bdl & bdl & bdl & bdl & bdl & bdl & bdl & bdl & bdl & bdl & bdl \\
\hline Ho & $(p p m)$ & 1,62 & 1,17 & 0,92 & 1,19 & 1,02 & 1,18 & 1,37 & 1,69 & 0,93 & 1,05 & 1,17 & 1,05 \\
\hline $\mathbf{Y}$ & $(p p m)$ & 9,77 & 10,60 & 9,25 & 8,94 & 4,85 & 5,58 & 7,52 & 8,07 & 9,76 & 5,96 & 2,61 & 1,61 \\
\hline Er & $(p p m)$ & n.a & n.a & n.a & n.a & n.a & n.a & n.a & n.a & n.a & n.a & n.a & n.a \\
\hline Tm & $($ ppm) & n.a & .a & n.a & n.a & n.a & n.a & n.a & n.a & n.a & n.a & n.a & n.a \\
\hline Yb & $(p p m)$ & 0,06 & 0,10 & 0,17 & 0,21 & 0,03 & 0,02 & bdl & 0,17 & 0,41 & 0,16 & bdl & 0,12 \\
\hline Lu & $(p p m)$ & 9,51 & 4,72 & 5,55 & 3,73 & 1,65 & 3,73 & bdl & bdl & 2,73 & 0,77 & 6,45 & 4,54 \\
\hline
\end{tabular}

Lantanum (La) dan Cerium (Ce) merupakan dua unsur yang memiliki kandungan paling tinggi dibanding unsur-unsur Logam Tanah Jarang (LTJ) lainnya (Tabel 3).

Tabel 3. Kandungan La dan Ce dalam bijih (ppm)

\begin{tabular}{c|cccc}
\hline Unsur & CLO & MGO & HGO & SGO \\
\hline La & $6-14,51$ & $20,22-22,66$ & $8,51-12,92$ & $13,79-14,46$ \\
Ce & $15,27-29,07$ & $38,55-45,57$ & $22,37-28,07$ & $27,06-33,78$ \\
\hline
\end{tabular}

Besi (Fe) merupakan kandungan terbesar di dalam konsentrat bijih dengan kadar ratarata $26 \%$. Kandungan lainnya terdiri dari $22 \% \mathrm{Cu}, 21 \%$ sulfur $(\mathrm{S}), 11 \%$ silika $\left(\mathrm{SiO}_{2}\right)$, dan $2 \%$ alumina (Al). Sebanyak 18\% sisanya terdiri dari unsur-unsur produk samping yaitu $11 \mathrm{ppm}$ Au dan 66 ppm Ag serta unsur-unsur ikutan lainnya (Gambar 4).

Konsentrat bijih memiliki kadar rata-rata 0,12\% Mo, 157 ppm As, 128 ppm Bi, 


\section{MAKALAH ILMIAH}

23 ppm Cd, 110 ppm Co, 39 ppm Ni, 931 ppm Pb, 0,37\% Zn, 4 ppm Sb, 174 ppm Se, 16 ppm Te, dan 145 ppm W.



Gambar 4. Diagram sebaran kandungan unsur-unsur dalam konsentrat bijih dari Grasberg, Tembagapura

$\mathrm{Ce}, \operatorname{Pr}$ dan $\mathrm{Gd}$ memiliki kadar rata-rata paling tinggi dibanding LTJ lainnya di dalam konsentrat bijih yaitu masing-masing 24 ppm, 29 ppm dan 37 ppm. LTJ lainya memiliki kadar rata-rata $\leq 20 \mathrm{ppm}$. Analisis kandungan unsur radioaktif dengan metode Spektrofotometri UV-Vis menunjukkan kandungan Th pada conto konsentrat bijih nomer 04C dan 05C masing-masing 284,25 ppm dan 99,32 ppm. Uranium tidak terdeteksi di dalam pengukuran ini.

Komposisi tailing didominasi oleh $56,88 \%$ $\mathrm{SiO}_{2}$, dengan kadar $\mathrm{Cu}, \mathrm{Au}, \mathrm{Ag}$ masingmasing 0,02\%, 0,23 ppm dan 16,5 ppm. La dan Ce memiliki kadar paling tinggi diantara LTJ lainnya di dalam tailing masing-masing 25,07 ppm dan 42,47 ppm. Kandungan LTJ lainnya berkisar antara 6 ppm sampai 28 ppm.

Hasil analisis kimia konsentrat bijih dan tailing selengkapnya ditampilkan dalam Tabel 4.

\section{PEMBAHASAN}

Kadar $\mathrm{Cu}, \mathrm{Au}$ dan $\mathrm{Ag}$ menunjukkan trend yang meningkat dari MGO-HGO-SGO (Gambar 5). Kadar $\mathrm{Cu}$ di dalam bijih ditentukan oleh kandungan mineral-mineral sulfida-Cu seperti kalkopirit $\left(\mathrm{CuFeS}_{2}\right)$, bornit $\left(\mathrm{Cu}_{5} \mathrm{FeS}_{4}\right)$, kalkosit $\left(\mathrm{Cu}_{2} \mathrm{~S}\right)$, dan kovelit (CuS). Demikian juga dengan kandungan $\mathrm{Au}$ dan Ag berasosiasi dengan mineralmineral sulfida tersebut (Simon drr., 2000; Kesler drr., 2002; Gregory drr., 2013).

Kadar rata-rata $\mathrm{Cu}, \mathrm{Au}$ dan $\mathrm{Ag}$ meningkat dari MGO-HGO-SGO (Gambar 5.a) sesuai deskripsi conto tipe bijih yang mencerminkan kandungan mineral-mineral sulfida. Berbeda dengan CLO, meskipun memiliki kadar kandungan $\mathrm{Cu}$, $\mathrm{Au}$ dan $\mathrm{Ag}$ yang tinggi, namun dipisahkan berdasar kandungan mineral lempung $(>10 \%)$ dan pirit $(>5 \%)$ yang memberikan kesulitan tersendiri di dalam proses flotasi menjadi konsentrat bijih.

Pengolahan bijih melalui proses flotasi yang menghasilkan konsentrat meningkatkan kadar (pengayaan) tembaga 21,6 kali (dari rata-rata kadar bijih $1 \%$ menjadi $21,6 \%$ pada konsentrat), emas 9,5 kali (1,5 ppm menjadi $11,1 \mathrm{ppm}$ ) dan perak 60 kali (5 ppm menjadi 66 ppm) (Gambar 5b).

Hasil dari proses flotasi terhadap bijih tembaga porfiri hampir selalu diikuti oleh kandungan unsur-unsur pengotor di dalam konsentrat bijihnya. Kandungan unsurunsur tertentu yang melebihi ambang yang ditetapkan bisa mengakibatkan denda yang akan mengurangi harga jual konsentrat. Sehingga proses flotasi tidak selalu memberikan peningkatan kadar dari unsurunsur ikutan yang ada. Karena produk utamanya tembaga-emas-perak, maka unsur-unsur ikutan lain terutama yang dianggap sebagai pengotor seperti $\mathrm{As}, \mathrm{Sb}$, $\mathrm{Bi}, \mathrm{Cl}, \mathrm{Pb}, \mathrm{Zn}, \mathrm{Ni}$, Co, Al, Mg, F, Hg dan Cd diupayakan untuk dibuang kandungannya ke dalam material tailing. 
Tabel 4. Hasil analisis kimia conto konsentrat dan tailing dari Grasberg

\begin{tabular}{|c|c|c|c|c|c|c|c|c|c|c|c|c|c|}
\hline \multicolumn{2}{|c|}{ No. Conto } & \multirow{2}{*}{$\begin{array}{r}\text { K_1 } \\
189000\end{array}$} & \multirow{2}{*}{$\begin{array}{r}\text { K_2 } \\
204400\end{array}$} & \multirow{2}{*}{$\frac{\text { K_3 }}{248100}$} & \multirow{2}{*}{$\begin{array}{r}\text { K_4 } \\
221400\end{array}$} & \multirow{2}{*}{$\begin{array}{r}\text { K_5 } \\
197800\end{array}$} & \multirow{2}{*}{$\begin{array}{r}\text { K_6 } \\
246300\end{array}$} & \multirow{2}{*}{$\begin{array}{r}\text { K_7 } \\
189300\end{array}$} & \multirow{2}{*}{$\begin{array}{r}\text { K_8 } \\
183400\end{array}$} & \multirow{2}{*}{$\begin{array}{r}\text { K_9 } \\
275000\end{array}$} & \multirow{2}{*}{$\begin{array}{r}\text { K_10 } \\
194000\end{array}$} & \multirow{2}{*}{$\frac{\text { K_11 }}{237000}$} & \multirow{2}{*}{$\begin{array}{r}\text { Tailing } \\
202\end{array}$} \\
\hline$\overline{\mathrm{Cu}}$ & (ppm) & & & & & & & & & & & & \\
\hline $\mathbf{P b}$ & (ppm) & 1200 & 1190 & 90 & 625 & 1190 & 900 & 1260 & 1170 & 640 & 1160 & 815 & 54 \\
\hline $\mathrm{Zn}$ & (ppm) & 4080 & 4240 & 3730 & 2205 & 4200 & 2850 & 4020 & 3690 & 2355 & 7400 & 2760 & 200 \\
\hline Co & (ppm) & 131 & 123 & 104 & 110 & 110 & 85 & 106 & 112 & 104 & 123 & 104 & 19 \\
\hline $\mathbf{N i}$ & (ppm) & 94 & 44 & 35 & 33 & 36 & 29 & 35 & 33 & 32 & 29 & 32 & 22 \\
\hline Mn & (ppm) & 403 & 398 & 345 & 227 & 394 & 253 & 364 & 340 & 229 & 318 & 229 & 621 \\
\hline $\mathrm{Ag}$ & (ppm) & 66,0 & 58,8 & 77,7 & 64,2 & 63,6 & 72,0 & 75,2 & 52,8 & 69,8 & 58,1 & 69,8 & 16,5 \\
\hline Li & (ppm) & 1 & 1 & 1 & bdl & 1 & bdl & 1 & 1 & bdl & 1 & 1 & 3 \\
\hline $\mathrm{Fe}$ & (\%) & 24,03 & 24,1 & 25,67 & 27,3 & 25,53 & 27,75 & 25,76 & 23,88 & 26,7 & 24,81 & 25,51 & 3,38 \\
\hline $\mathbf{B i}$ & (ppm) & 197 & 143 & 128 & 103 & 136 & 105 & 124 & 125 & 107 & 132 & 112 & 68 \\
\hline $\mathrm{Ca}$ & (ppm) & 1644 & 1429 & 1904 & 1708 & 1350 & 1571 & 1614 & 1416 & 1479 & 1335 & 1577 & 1297 \\
\hline Cd & (ppm) & 23 & 32 & 24 & 18 & 23 & 21 & 23 & 22 & 19 & 23 & 21 & 6 \\
\hline Mg & (ppm) & 4146 & 4114 & 2880 & 2534 & 4089 & 3273 & 4172 & 4042 & 2811 & 3959 & 3332 & 14900 \\
\hline $\mathrm{Cr}$ & (ppm) & 9 & 3 & 3 & bdl & 5 & 2 & 6 & 3 & 4 & 10 & 1 & 138 \\
\hline $\mathrm{Au}$ & (ppm) & 6,14 & 10,35 & 20,25 & 7,98 & 8,8 & 7,998 & 12,17 & 9,86 & 14,06 & 12,26 & 12,4 & 0,23 \\
\hline Al & (\%) & 2,83 & 2,84 & 1,90 & 2,03 & 2,82 & 1,99 & 2,82 & 3,06 & 2,29 & 2,81 & 1,91 & 12,04 \\
\hline $\mathrm{Ti}$ & (\%) & 0,20 & 0,20 & 0,20 & 0,18 & 0,18 & 0,17 & 0,18 & 0,26 & 0,20 & 0,22 & 0,20 & 0,30 \\
\hline SiO & (\%) & 0,90 & 0,00 & 0,00 & 0,00 & 2,71 & 64,71 & 2,11 & 0,00 & 42,33 & 7,14 & 0,44 & 56,88 \\
\hline $\mathbf{V}$ & (ppm) & 20 & 20 & 20 & 20 & 20 & 20 & 30 & 20 & 20 & 20 & 20 & 80 \\
\hline $\mathrm{Sb}$ & (ppm) & 7 & 5 & 2 & 2 & 6 & 4 & 4 & 7 & 1 & 6 & 3 & 2 \\
\hline Sn & (ppm) & 120 & bdl & bdl & 30 & 70 & 20 & bdl & bdl & bdl & bdl & bdl & bdl \\
\hline As & (ppm) & 175,14 & 177,02 & 116,69 & 144,09 & 213,21 & 148,54 & 180,98 & 179,38 & 98,35 & 211,08 & 6,86 & 12,48 \\
\hline Sc & (ppm) & 15,88 & 15,39 & 16,18 & 15,67 & 15,42 & 15,93 & 15,16 & 15,40 & 15,93 & 15,66 & 5,99 & 17,40 \\
\hline $\mathrm{Zr}$ & (ppm) & 18 & 17 & 17 & 17 & 18 & 17 & 18 & 18 & 17 & 17 & 17 & 20 \\
\hline $\mathbf{R b}$ & (ppm) & 39,60 & 38,12 & 24,96 & 30,28 & 38,16 & 27,10 & 38,94 & 39,43 & 26,14 & 39,02 & 25,84 & 112,26 \\
\hline $\mathrm{Nb}$ & (ppm) & 2,58 & 2,33 & 2,82 & 2,58 & 3,23 & 2,36 & 2,33 & 4,09 & 2,94 & ,81 & & 5,72 \\
\hline Mo & (ppm) & 1794,33 & 51,05 & 699,76 & 89,45 & 767,51 & 00 & 68,01 & 795,04 & 87,88 & ,37 & 32 & 0,62 \\
\hline $\mathrm{Te}$ & (ppm) & 23,98 & 6,96 & 55 & 7,93 & 14,78 & 38 & 4,51 & 11,95 & 9,20 & 21 & 86 & bdl \\
\hline $\mathrm{Ta}$ & (ppm) & 520,44 & 87,96 & 700,32 & 593,27 & 490,37 & 676,23 & 492,42 & 487,79 & 679,13 & & 687,06 & 2,84 \\
\hline $\mathbf{w}$ & (ppm) & 143,62 & 153,44 & 156,64 & 142,25 & 141,34 & 158,89 & 125,86 & 119,67 & 152,90 & 146,46 & 157,13 & 17,15 \\
\hline $\mathrm{Se}$ & (ppm) & 170,31 & 161,20 & 193,67 & 176,33 & 164,49 & 164,97 & 167,92 & 179,88 & 186,85 & 167,84 & 181,94 & bdl \\
\hline $\mathbf{S}$ & (\%) & 20,96 &, 93 & 19,42 & 21,26 & 21,61 & 18,56 & 22,11 & 23,22 & 20,77 & 21,51 & 20,84 & 1,85 \\
\hline $\mathrm{Cl}$ & (\%) & bdl & bdl & bdl & bdl & bdl & bdl & bdl & bdl & bdl & bdl & bdl & bdl \\
\hline $\mathbf{U}$ & (ppm) & na & na & bdl & bdl & na & na & na & na & na & na & na & na \\
\hline Th & (ppm) & na & na & 284,25 & 99,32 & na & na & na & na & na & na & na & na \\
\hline La & (ppm) & 3,92 & 3,82 & 19,22 & 14,78 & 14,08 & 2,47 & 14,80 & 15,42 & 18 & 3,72 & & 25,07 \\
\hline $\mathrm{Ce}$ & (ppm) & 21,02 & 24,97 & 12 & 26,60 & 23,44 & 68 & 23,66 & 24,75 & 20,45 & 21,64 & & 42,47 \\
\hline $\operatorname{Pr}$ & (ppm) & 30,30 & 3,00 & ,73 & 29,47 & 31,52 & 44 & 18 & 29,11 & 12 & 33,78 & 67 & 21,09 \\
\hline Nd & (ppm) & 9,61 &, 88 & 24,43 & 20,16 & 22,00 & 30 & 61 & 20,66 & 18,42 & 20,38 & 19,50 & 28,30 \\
\hline Sm & (ppm) & 2,13 & 16,68 & 13,12 & 12,56 & & 48 & & & & & & 14,79 \\
\hline Eu & (ppm) & 19,34 & 19,29 & 19,22 & 19,07 & 19,25 & 19,06 & & & 19,02 & & & 19,66 \\
\hline Gd & (ppm) & 36,71 & 33,63 & 36,88 & 38,68 & 36,05 & 37,29 & 34,36 & 35,87 & 37,64 & 8,09 & 38,42 & 15,12 \\
\hline Tb & (ppm) & 17,21 & 16,58 & 17,36 & 15,92 & 16,68 & 16,46 & 16,36 & 15,66 &, 82 &, 62 & 16,40 & 13,26 \\
\hline Dy & (ppm) & 11,17 & 11,01 & 11,01 & 11,49 & 11,32 & 11,04 & 10,87 & 11,65 & 11,15 & 11,56 & 11,38 & 13,01 \\
\hline Ho & (ppm) & 13,62 & 13,47 & 12,88 & 13,38 & 14,15 & 13,09 & 13,09 & 13,02 & 12,93 & 13,08 & 13,57 & 12,96 \\
\hline $\mathbf{Y}$ & (ppm) & 11,88 & 11,66 & 11,90 & 11,40 & 11,45 & 11,08 & 11,57 & 11,56 & 11,21 & 11,76 & 12,13 & 18,53 \\
\hline $\mathrm{Er}$ & (ppm) & na & na & na & na & na & na & na & na & na & na & na & na \\
\hline $\mathrm{Tm}$ & (ppm) & 9,69 & 9,48 & 9,17 & 9,50 & 9,72 & 9,46 & 9,85 & 9,36 & 9,27 & 9,56 & 9,79 & 8,94 \\
\hline $\mathrm{Yb}$ & (ppm) & 12,17 & 11,78 & 11,87 & 12,01 & 11,91 & 11,94 & 11,75 & 11,87 & 11,92 & 11,95 & 12,05 & 11,00 \\
\hline Lu & (ppm) & 20,18 & 10,51 & 15,85 & 12,14 & 16,18 & 10,29 & 8,36 & 11,93 & 12,29 & 12,33 & 10,32 & 6,02 \\
\hline
\end{tabular}




\section{MAKALAH ILMIAH}

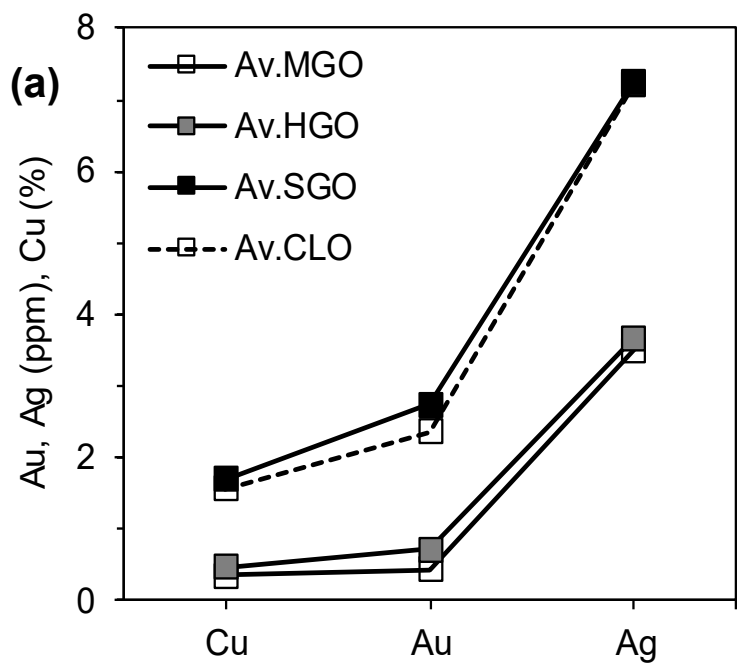

Kadar unsur-unsur pengotor yang tinggi akan memberikan permasalahan terhadap lingkungan dan kesehatan. Selain itu denda atau penolakan dari konsumen (pabrik pemurnian/smelter) karena akan menambah biaya pengelolaan limbah, biaya modal pabrik pemurnian, biaya operasi keseluruhan, dan mengurangi kualitas katoda-Cu yang pada akhirnya akan mempengaruhi pendapatan.

Kandungan unsur-unsur pengotor dari konsentrat Grasberg masih di bawah batas kandungan unsur pengotor untuk smelter baik di Jepang maupun di Tiongkok (Tabel 5). Demikian juga dengan kadar alumina (Al), kadar $2 \%$ dari konsentrat Grasberg masih dibawah kadar maksimal pengotor sebesar 3\% (Pardiarto, 2007).

Unsur-unsur radioaktif seperti uranium (U) dan thorium (Th) juga dianggap sebagai pengotor dan memberikan kesulitan di dalam pengelolaannya.

Dari 2 conto konsentrat bijih yang dianalisis kandungan radioaktifnya, $U$ tidak terdeteksi kadarnya, namun memiliki kandungan 99,32 ppm dan 284,25 ppm Th. Kadar Th dalam konsentrat bijih Grasberg tersebut jauh lebih kecil dibanding kadar dari bijih yang ditambang di Arax'a, Brazil yaitu $0,10 \%$ Th pada intrusi alkalin (Jordan drr., 2015). dan Ag. (a) Dalam masing-masing tipe bijih, (b) dalam bijih, konsentrat dan tailing

Tabel 5. Kadar maksimal kandungan pengotor konsentrat untuk smelter di Jepang dan Cina (Fountain, 2013) dan kandungan unsur pengotor dari Grasberg

\begin{tabular}{lccr}
\hline \multirow{2}{*}{ Unsur } & \multicolumn{2}{c}{ Kadar maksimal } & \multicolumn{2}{c}{$\begin{array}{c}\text { Rata-rata } \\
\text { Grasberg (\%) }\end{array}$} \\
\cline { 2 - 3 } & \multicolumn{2}{c}{ Jepang } & \multicolumn{2}{c}{ Cina } & 0,0157 \\
\hline \hline $\mathrm{As}$ & $0,2 \%$ & $0,5 \%$ & 0,0004 \\
$\mathrm{Sb}$ & $0,1 \%$ & - & 0,0128 \\
$\mathrm{Bi}$ & $0,05 \%$ & - & Tidak terdeteksi \\
$\mathrm{Cl}$ & $0,05 \%$ & - & 0,0931 \\
$\mathrm{~Pb}$ & $1 \%$ & $6 \%$ & 0,3775 \\
$\mathrm{Zn}$ & $3 \%$ & - & 0,0149 \\
$\mathrm{Ni}+\mathrm{Co}$ & $0,5 \%$ & - & Tidak dianalisis \\
$\mathrm{Al}_{2} \mathrm{O}_{3}+\mathrm{MgO}$ & $5 \%$ & - & Tidak dianalisis \\
$\mathrm{F}$ & $330 \mathrm{ppm}$ & $0,1 \%$ & Tidak dianalisis \\
$\mathrm{Hg}$ & $10 \mathrm{ppm}$ & $0,01 \%$ & 0,0022 \\
$\mathrm{Cd}$ & - & $0,05 \%$ &
\end{tabular}


Kadar Mo rata-rata pada bijih adalah 19,7 ppm. Proses flotasi mengakibatkan pengayaan kadar Mo pada konsentrat menjadi $0,1 \%$, sementara tailing masih mengandung 10,6 ppm Mo. Kadar ini belum ekonomis, dimana kadar pada bijih atau bahkan pada konsentrat yang sudah mengalami pengayaan masih di bawah kadar tipe bijih yang ekonomis yaitu $0,3 \%$ (Ridley, 2013).

Hasil analisis kimia terhadap bijih dan konsentrat bijih menunjukkan kandungan $\mathrm{Li}$ masing-masing 2,9 ppm dan $1 \mathrm{ppm}$. Hal ini menunjukkan adanya pengurangan kadar $\mathrm{Li}$ akibat flotasi bijih dan terbuang ke tailing yang memiliki kadar 3 ppm. Kadar tersebut masih di bawah rata-rata kadar Li batuan beku 28 ppm s.d. 30 ppm dan pada batuan sedimen 53 ppm s.d. 60 ppm (Evans, 2014; Kunasz, 2006). Penambangan Li sebagian besar diambil dari brines dengan kadar $\mathrm{Li}_{2} \mathrm{O}$ di atas $0,01 \%$ (Anonim, 2016). Penambangan Li dari batuan pegmatit salah satunya di Greenbushes, Australia memiliki kadar rata-rata $\mathrm{Li}_{2} \mathrm{O}$ di atas $2 \%$ (Ingham drr, 2012). Kadar Li dari bijih penambangan Grasberg tersebut masih sangat jauh di bawah kadar ekonomis penambangan $\mathrm{Li}$ dari pegmatit.

Kadar $\mathrm{V}$ rata-rata pada bijih adalah $61 \mathrm{ppm}$ dan di dalam konsentrat $21 \mathrm{ppm}$. Hal tersebut menunjukkan terjadi pembuangan $\mathrm{V}$ dalam proses flotasi dan terbawa ke dalam tailing yang memiliki kadar 80 ppm. $\mathrm{Di}$ dalam bijih porfiri keberadaan $\mathrm{V}$ tidak ekonomis karena pada umumnya merupakan by- atau co-product dari vanadium-bearing slag hasil pemrosesan besi atau uranium yang bisa mengandung $10-25 \%$ vanadium pentoxide $\left(\mathrm{V}_{2} \mathrm{O}_{5}\right)$.

Conto bijih dan konsentrat dari Grasberg masing-masing memiliki rata-rata kadar Sc sebesar 4,6 ppm dan 16 ppm. Kadar tersebut sangat rendah dibandingkan dengan kadar bijih dari produsen Sc terbesar di dunia (90\%) Bayan Obo, Cina, Sc merupakan by-product LTJ dan terkandung dalam mineral aegirine dengan rata-rata kadar 210 ppm (Zhao, 1987).
Hasil analisis kimia terhadap bijih dan konsentrat menunjukkan kandungan $\mathrm{Rb}$ masing-masing 90 ppm dan 33 ppm. Kadar tersebut masih sangat rendah jika dibandingkan dengan kadar $\mathrm{Rb}$ yang sudah di produksi dari batuan pegmatit di Pakeagama Lake yang memiliki kadar berkisar antara $0,97 \%$ s.d. 1,2\% di dalam Kfeldspars (Butterman dan Reese Jr, 2003).

Bijih dan konsentrat masing-masing memiliki rata-rata kadar $\mathrm{Nb}$ sebesar 5,2 ppm dan 2,8 ppm. Proses flotasi menurunkan kadar $\mathrm{Nb}$ dalam konsentrat dan terbuang ke dalam tailing yang mengandung 5,7 ppm $\mathrm{Nb}$. Ta pada bijih dan konsentrat bijih masing-masing memiliki rata-rata kadar Ta sebesar 14 ppm dan 575 ppm. Kadar Nb dan $\mathrm{Ta}$ tersebut masih dibawah kadar signifikan cebakan porfiri-Mo pada granit alkali yang mengandung $0,1 \% \quad \mathrm{Nb}_{2} \mathrm{O}_{5}$ dan 0,1\% $\mathrm{Ta}_{2} \mathrm{O}_{5}$ (Long, 1992; Anonim, 2011).

Te dan Se merupakan unsur ikutan yang berpotensi memiliki nilai ekonomis di dalam konsentrat tembaga. Kadar Te rata-rata dari bijih dan konsentrat bijih masing-masing 2,7 ppm dan 16 ppm. Kadar dalam bijih tersebut masih dalam kisaran tipe kadar Te sebagai produk samping dalam cebakan tipe porfiri 1 ppm s.d. 10 ppm (John dan Taylor, 2016). Te pada umumnya diambil dari anoda slime yang memiliki kadar Te maksimum 5\%. (Tomakchieva, 2002; Weerts, 2002; Goldfarb drr., 2017).

Kadar Se rata-rata pada bijih sebesar 6,4 ppm lebih tinggi dari kadar rata-rata pada batuan beku (0,05 ppm), batupasir $(0-0,5$ ppm), serpih ( $0-0,6 \mathrm{ppm})$, batugamping $(0,08 \mathrm{ppm})$ dan soil $(0,2 \mathrm{ppm})$ (Wang drr, 2016). Namun demikian kadar tersebut masih lebih rendah dari kadar kandungan Se yang diproduksi yaitu di atas $10 \mathrm{ppm}$ (Wang drr, 2016). Proses konsentrasi telah meningkatkan kadar Se menjadi 174 ppm atau sekitar 27 kali dari kadar pada bijih. Seperti halnya Te, Se diproduksi dari lumpur anoda dalam pemurnian bijih tembaga (Butterman and Brown, 2004; George, 2012). Lumpur anoda ini rata-rata memiliki kadar sekitar $7 \mathrm{wt} \%$ Se, dan ada yang 


\section{MAKALAH ILMIAH}

mencapai 40\% Se (Weerts, 2002; Moats drr., 2007; Goldfarb drr., 2017). Sumber utama produksi Te dan Se di dunia adalah dari produk samping proses pemurnian bijih tembaga tipe porfiri (Goldfarb drr., 2017).

Dalam kajian ini tidak dilakukan analisis kimia terhadap kandungan unsur-unsur kelompok platina (PGE). Hutabarat (2017) menyebutkan konsentrat tembaga yang diambil dari Grasberg, Papua memiliki kandungan paladium $(\mathrm{Pd})$ dan platinum $(\mathrm{Pt})$ masing-masing $1700 \mathrm{ppb}$ dan $650 \mathrm{ppb}$. Kandungan PGE tersebut lebih tinggi dibanding kompilasi dari konsentrat hasil proses flotasi beberapa cebakan tembaga porfiri di dunia yaitu $16 \mathrm{ppb}$ - $760 \mathrm{ppb} \mathrm{Pd}$ dan Pt berkisar antara 8 ppb sampai 570 ppb (Tarkian drr., 1999), atau bahkan lebih tinggi dibanding konsentrat dari cebakan porfiri $\mathrm{Cu}-\mathrm{Au}$ (Pd-Pt-Te) Skouries, Yunani yang memiliki kandungan rata-rata 1625 ppb Pd dan 33 ppb Pt (McFall drr, 2018). Cebakan porfiri-Cu yang kaya akan Au merupakan target yang menjanjikan untuk mencari $\mathrm{Pd}$ and Pt (John dan Taylor, 2016).

Diagram log dari hasil normalisasi kadar LTJ dari bijih Grasberg terhadap chondrite (McDonough dan Sun, 1995) menunjukkan pola yang berbeda dengan kandungan LTJ dari kerak bumi bagian atas (Taylor dan McLennan, 1981) (Gambar 6). Pola umum diagram log kadar LTJ pada batuan adalah menunjukkan pengayaan Light Rare Earth Element (LREE; La-Sm) dan berkurangnya Heavy Rare Earth Element (HREE; Gd-Yb). Pola diagram log yang berbeda tersebut menunjukkan adanya suatu "anomali" kandungan LTJ pada bijih, namun nilai kadarnya masih jauh sangat rendah untuk dikatakan ekonomis.

Proses flotasi secara umum mengakibatkan pengkayaan unsur LTJ pada konsentrat, kecuali Ce. Kadar La, Ce, Nd dan Y di dalam tailing lebih besar dibanding di dalam konsentrat, yang menunjukkan terbuangnya unsur-unsur tersebut akibat proses flotasi (Gambar 7).

Kadar pada bijih dan konsentrat tembaga Grasberg menunjukkan beberapa mineral ikutan yang berpotensi untuk diambil dan memiliki nilai ekonomis selain $\mathrm{Cu}, \mathrm{Au}$ dan Ag. Unsur-unsur ikutan berupa $\mathrm{Se}, \mathrm{Te}, \mathrm{Pd}$ dan $\mathrm{Pt}$ berpotensi untuk diambil sebagai unsur ikutan yang memiliki nilai ekonomis dari lumpur anoda. Hal ini didukung oleh hasil analisis kandungan lumpur anoda dari sisa pemurnian konsentrat Grasberg di PT Smelting (Saleh, 2012) yang mengandung $1 \% \mathrm{Au}, 3,8 \% \mathrm{Ag}, 2,7 \% \mathrm{Bi}, 75 \mathrm{ppm} \mathrm{Pd}$, $0,0015 \% \mathrm{Pt}, 0,21 \%$ Te, $6,52 \%$ Se dan $55 \%$

$\mathrm{Pb}$ dan $7 \%$ komponen logam lain.

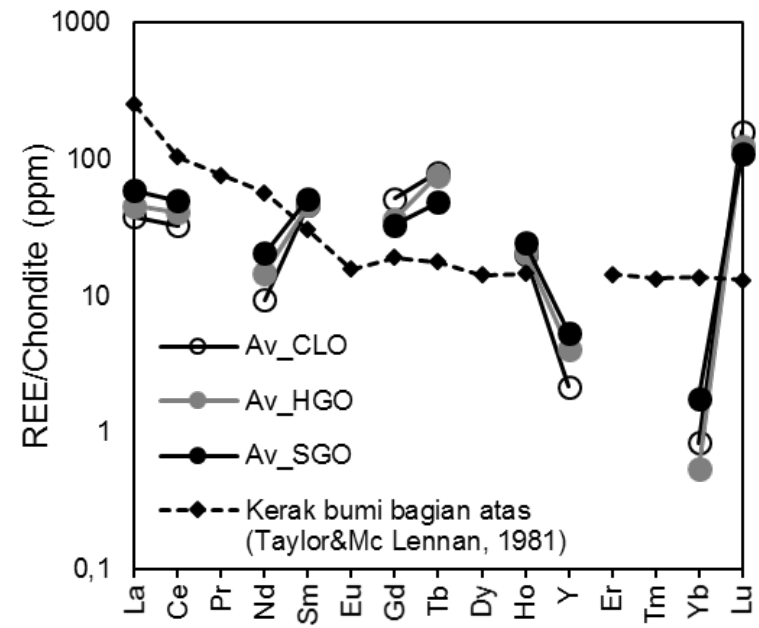

Gambar 6. Perbandingan kadar unsur LTJ beberapa conto bijih dari Grasberg,

Tembagapura terhadap kadar rata-rata kerak bumi bagian atas

(Taylor dan Mc Lennan, 1981)

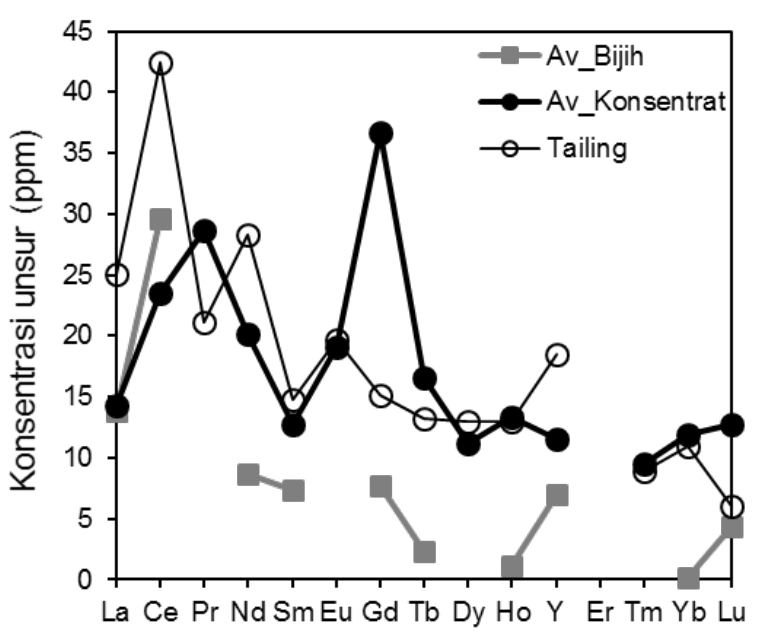

Gambar 7. Perbandingan konsentrasi unsur LTJ masing-masing conto dari Grasberg, Tembagapura 


\section{KESIMPULAN DAN SARAN}

Bijih tembaga tipe porfiri dari Grasberg mengandung beberapa unsur ikutan, yang potensi kandungannya baru bisa dievaluasi dari kadar bijih dan konsentrat yang dihasilkan dari proses flotasi dan dari lumpur anoda sisa pemurnian tembaga seperti platinum, palladium, telurium dan selenium.

Dikarenakan unsur-unsur tersebut muncul dalam kadar yang sedikit, maka nilai keekonomiannya juga ditentukan oleh besarnya volume bijih yang diproses dan teknologi pemisahannya dari lumpur anoda.

Untuk menindaklanjuti hasil penelitian ini, perlu dilakukan penyelidikan lebih lanjut terhadap lumpur anoda sisa pemurnian tembaga meliputi kadar unsur-unsur ikutan yang dikandungnya dan teknologi pemisahannya untuk mendapatkan nilai ekonomis dari unsur-unsur ikutan tersebut.

\section{UCAPAN TERIMA KASIH}

Terima kasih kepada Kepala Pusat, Kepala Bidang Mineral, Kepala Sub Bidang Mineral Logam Pusat Sumber Daya Mineral, Batubara dan Panasbumi atas kebijakan dan fasilitasinya sehingga kegiatan penelitian ini bisa terlaksana. Dukungan dan kerja sama dari Tim evaluasi mineral ikutan pada endapan tipe porfiri dan staf Laboratorium PSDMBP di dalam melaksanakan penelitian ini sangat berarti. Terima kasih yang sebesar-besarnya kepada management PT FI terutama Ir. Wahyu Sunyoto, M.Sc., Ir. Nur Wiwoho, Yulius Sirait, ST. beserta Ahli Geologi dan staf di penambangan Grasberg atas dukungan pengumpulan conto, data dan diskusinya sehingga tulisan ini dapat tersusun.

\section{DAFTAR PUSTAKA}

Anonim, 2011, Niobium-tantalum. British Geological Survey.

Anonim, 2016, Lithium. British Geological Survey.
Anonim, 2018, Uranium Resources as Coand By-products of Polymetallic, Base, Rare Earth and Precious Metal Ore Deposits. International Atomic Energy Agency. Austria.

Anonim, https://ptfi.co.id/id/how-do-weoperate (PT. Freeport Indonesia, 2019) diakses 30 Januari 2019; 08.50.

Anonim,http://www.ptsmelting.com/product diagram.htm. diupload 2005. diakses 30 Januari 2019; 12.20.

Austen, G. and Ballantyne, G., 2010, Geology and geochemistry of deep molybdenum mineralization at the Bingham Canyon mine, Utah, USA. Society of Economic Geologists Guidebook Series, 41, h. 35-49.

Ayres, R.U., Ayres, L.W. and Råde, I., 2002, The Life Cycle of Copper, its CoProducts and By-Products. World Business Council for Sustainable Development.

Butterman, W.C. and Reese Jr. R.G., 2003, Mineral Commodity Profiles Rubidium. USGS.

Cannell, J., Cooke, D. R., Walshe, J. L. and Stein, H., 2005, Geology, mineralization, alteration, and structural evolution of the El Teniente porphyry Cu-Mo deposit. Economic Geology, 100, h. 979-1003.

Cooke, D. R., Hollings, P., Wilkinson, J. J. and Tosdal, R. M., 2014, Geochemistry of porphyry deposits.

Cooke, D. R., Hollings, P. and Walshe, J. L., 2005, Giant porphyry deposits: characteristics, distribution, and tectonic controls. Economic geology, 100 , h. 801-818.

Dahlkamp, F. J., 2009, Uranium deposits of the world, USA and Latin America: Berlin, Springer-Verlag, v. 4, $516 \mathrm{~h}$.

Davis, A., Ruby, M. V., Bloom, M., Schoof, R., Freeman, G. and Bergstrom, P. D., 1996, Mineralogical constraints on the bioavailability of arsenic in smelterimpacted soils. Environmental Science and Technology, 30, h. 392399.

Evans, R. K., 2014, Lithium. Di dalam: Gunn, A.G. (Ed), 2014. Critical Metals Handbook Chapter 10. John Wiley \& Sons Ltd. Chichester, UK. 
Fountain, C., 2013, The Whys and Wherefores of Penalty Elements in Copper Concentrates. Metallurgical Plant Design and Operating Strategies Metplant 2013.

Garwin, S. L., 2002. The geologic setting of intrusion-related hydrothermal systems near the Batu Hijau porphyry copper-gold deposit, Sumbawa, Indonesia. Society of Economic Geologists Special Publication 9, h. 333-366.

Goldfarb, R. J., Berger, B. R., George, M. W. and Seal II. R.S., 2017, Tellurium. Di dalam: Schulz, K. J., DeYoung, Jr. J. H., Seal II, R. S. dan Bradley, D. C. (Ed.), 2017, Critical Mineral Resources of the United StatesEconomic and Environmental Geology and Prospects for Future Supply. USGS.

Heidrick, T. L. dan Titley, S. R., 1982, Fracture and dike patterns in Laramide plutons and their structural and tectonic implications. University of Arizona Press, Tucson.

Hutabarat, I. 2017, Karakterisasi konsentrat tembaga Indonesia untuk diklat peningkatan nilai tambah tembaga. Geominerba 1, h. 23-28.

Ingham, P. D., White, I. R. and Jackson, S., 2012, Greenbushes Lithium Operations. Talison Lithium Ltd. Technical Report.

John, D. A. dan Taylor, R. D., 2016, ByProducts of Porphyry Copper and Molybdenum Deposits. Di dalam Verplanck, P. L. dan Hitzman, M.W., (Ed.), 2016, Rare Earth and Critical Elements in Ore Deposits. Reviews in Economic Geology, 18, h. 137-164.

Jordan, B. W., Eggert, R. G., Dixon, B. W., and Carlsen, B. W., 2015, Thorium: Crustal Abundance, Joint Production, and Economic Availability. U.S. Department of Energy Office of Nuclear Energy.
Gregory, M. J., Lang, J. R., Gilbert, S. and Hoal, K.O., 2013, Geometallurgy of the Pebble porphyry copper-goldmolybdenum deposit, Alaska: Implications for gold distribution and paragenesis. Economic Geology 108, h. 463-482.

Kesler, S. E., Chryssoulis, S. L. and Simon, G., 2002, Gold in porphyry copper deposits: its abundance and fate. Ore Geology Review 21, h. 103-124

Kunasz, I., 2006, Lithium Resources, in Kogel, J. E., Tridevi, N. C., Barker, J. M. and Krukowski, S.T. (Ed.), 2006, Industrial Minerals and Rocks, 7th Edition. h. 599-613, Society for Mining, Metallurgy and Exploration Inc, Litteton, Colorado, USA.

Kirkham, R. V., 1972, Porphyry deposits. Report of Activities: Geological Survey of Canada, Paper, pp.72-1.

Long, K. R., 1992, Reserves and production data for selected ore deposits in the United States found in the files of the Anaconda Copper Company: U.S. Geological Survey Open-File Report 92-002. $21 \mathrm{p}$.

Lowell, J. D. dan Guilbert, J. M., 1970, Lateral and vertical alterationmineralization zoning in porphyry ore deposits. Economic Geology, 65, h. 373-408.

Lynch, D. C, Agaki, S. dan Davenport, W. G., 1991, Thermochemical nature of minor elements in copper smelting mattes. Metallurgical Transactions $B$, 22B: h. 667-688.

MacDonald, G. D dan Arnold, L. C., 1993, Geological and Geochemical zoning of the Grasberg Igneous Complex, Irian Jaya, Indonesia. Journal of Geochemical Exploration 50, h. 143178.

McDowell, F. W., McMahon, T. P., Warren, P. Q. and Cloos, M., 1994, Intrusive and mineralization history of the Grasberg deposit, Irian Jaya, Indonesia. A.I.M.E. Preprint Number 3-92, $10 \mathrm{~h}$. 
McFall, K. A., Naden, J., Roberts, S., Baker, T., Spratt, J. dan McDonald, I., 2018, Platinum-group minerals in the Skouries Cu-Au (Pd, Pt, Te) porphyry deposit. Ore Geology Reviews, 99, h. 344-364.

McLemore, T., 2018, Rare Earth Elements (REE) Deposits Associated with Great Plain Margin Deposits (AlkalineRelated), Southwestern United States and Eastern Mexico Virginia. Resources, 7, h. 42-44.

Melfos, V. and Voudouris, P.C., 2012, Geological, Mineralogical and Geochemical Aspects for Critical and Rare Metals in Greece. Minerals, 2, h. 300-317.

Newell, J. M. dan Peatfield, G. R., 1995, The Red-Chris porphyry copper-gold deposit, northwestern British Columbia; Di dalam T. G. Schroeter (ed.), 1995, Porphyry Deposits of the Northwestern Cordillera of North America, Canadian Institute of Mining, Metallurgy and Petroleum, 46, h. 674688.

Pardiarto, B., 2007, Ringkasan tentang PT Freeport Indonesia dan PT Newmont Nusa Tenggara

Plant, J. A., Simpson, P. R., Smith, B. dan Windley, B. F., 1999, Uranium ore deposits-products of the radioactive Echo Bay U-Ni-Ag-Cu deposits, North West Territories, Canada. Economic Geology, 68, h. 635-656.

Pollard, P. J. dan Taylor, R. G. 2005, Ages of Intrusion, Alteration, and Mineralization at the Grasberg $\mathrm{Cu}-\mathrm{Au}$ Deposit, Papua, Indonesia. Economic Geology, 100, h.1005-1020.

Ridley, J., 2013, Ore deposit geology. Cambridge University Press.

Saleh, R., 2012, Increase Potential in ValueAdded of the Associated Metals from Copper Refining. Jurnal Teknologi Mineral dan Batubara, 8, h. 17-27.

Sapiie, B. dan Cloos, M., 2013, Strike-slip faulting and veining in the Grasberg giant porphyry $\mathrm{Cu}-\mathrm{Au}$ deposit, Ertsberg (Gunung Bijih) mining district, Papua, Indonesia. International Geology Review, 55, h. $1-42$.
Seedorff, E., 2005, Porphyry deposits: characteristics and origin of hypogene Features. Society of economist Geologists, Inc. Economic Geology 100th Anniversary Volume. Canada.

Sillitoe, R. H., 2010, Porphyry copper systems. Economic Geology, 105, h. 3-41.

Sillitoe, R., 1979, Some thoughts on goldrich porphyry copper deposits. Mineralium Deposita, 14, h. 161-174.

Sillitoe, R. H., 2002, Some metallogenic features of gold and copper deposits related to alkaline rocks and consequences for exploration. Mineralium Deposita, 37, h. 4-13.

Sillitoe, R. H., 1980, Types of porphyry molybdenum deposits. Mining Magazine, 142, h. 550-553.

Sillitoe, R. H., 1995. Exploration of porphyry copper lithocaps. Di dalam Pacrim Congress 1995 'Exploring the Rim' (h. 527-532). Aust. Inst. Mining Metall.

Simon. G., Kesler, S. E., Essene, E. J. and Chryssoulis, S. L., 2000, Gold in porphyry copper deposits: experimental determination of the distribution of gold in the $\mathrm{Cu}-\mathrm{Fe}-\mathrm{S}$ system at $400^{\circ}$ to $700^{\circ} \mathrm{C}$. Economic Geology, 95, h. 259-270.

Sinclair, W. D., 2007, Porphyry deposits. Mineral deposits of Canada: $A$ synthesis of major deposit-types, district metallogeny, the evolution of geological provinces, and exploration methods. Geological Association of Canada, Mineral Deposits Division, Special Publication, 5, h. 223-243.

Tarkian, M. and Stribrny, B., 1999, Platinumgroup elements in porphyry copper deposits: A reconnaissance study. Mineralogy and Petrology, 65, h. 161183.

Taylor, R. D., Hammarstrom, J. M., Piatak, N. M. dan Seal II, R. R., 2012, Arcrelated porphyry molybdenum deposit model: Chapter D in Mineral deposit models for resource assessment (No. 2010-5070-D). US Geological Survey.

Tokmakchieva, M., 1999, Bornite mineralization in the content of copper deposits in our country. Geology and Mineral Resources, No. 8-9, h. 40-44. 


\section{MAKALAH ILMIAH}

Tokmakchieva, M., 2002, Valuable minor components in the composition of porphyry copper deposits. Annual of the University of Mining and Geology "St. Ivan Rilski," Sofa, Bulgaria, 45, pt. 1, h. $71-75$

Weerts, P., 2002, Umicore streamlines precious recovery: Metal Bulletin Monthly/Copper Supplement, issue 374, February, 36h.
Wang, C., Li, S., Wang, H. dan Fu, J., 2016, Selenium minerals and the recovery of selenium from copper refinery anode slimes. The Journal of The Southern Africa Institute of Mining and Metallurgy, 116, h. 593-600.

Watterson, J. R., Gott, G. B., Neuerburg, G. J., Lakin, H. W. dan Cathrall, J. B., 1977, Tellurium, a guide to mineral deposits. Journal of Geochemical Exploration, 8, h. 31-48.

Zhao, C. 1987, Bayan Obo scandium. Baogangkeji, 04, h. 1-4.

$\begin{array}{ll}\text { Diterima } & : \text { 15 Februari } 2019 \\ \text { Direvisi } & : 22 \text { Maret } 2019 \\ \text { Disetujui } & : 28 \text { Mei } 2019\end{array}$

